\title{
Bank Performance and the Relationship between Lending and Fee-based Activities in an Emerging Market
}

\author{
Van Dan Danga \\ Banking University of Ho Chi Minh City
}

\begin{abstract}
New banking reforms in Vietnam highlight requirements for banks to diversify into the non-lending business lines. In this study, we analyse the reciprocal relationship between bank lending and fee-based activities and examine the comparative effects of two segments on bank performance in the Vietnamese market from 2007 to 2018. Employing the system of equations with the three-stage least squares (3SLS) estimator and different sets of variables, we find an inverse reciprocal relationship between bank lending ratio and fee-based income share and thereby contribute to the "loss leaders" hypothesis. For bank performance analyses, we apply a rich set of alternative measures for bank profitability, risk-adjusted profits and bank risk, estimated by the generalized method of moments (GMM) estimator for the dynamic panel framework. The results indicate benefits of economies of scope and differences in the risk-return mechanism of lending and fee-based activities. More precisely, we find fee income to positively affect returns on assets/equity and risk-adjusted profits. In sharp contrast, increased lending boosts net interest margins but contains more risks as shown by higher loss provision levels. The essential discrepancy between the two categories of activities has created an interesting risk-return trade-off pattern.
\end{abstract}

Keywords: Fee-based activities, lending, system of equations, trade-off, Vietnam JEL classification: G20, G21, G28

\section{Introduction}

Financial integration in Vietnam has created increasing competitive pressure and promoted the diversification of services in the banking sector. Starting from a system mostly focusing on lending to fuel the economy, the Vietnamese banking industry has gradually shown a shift toward non-interest segments. Especially with the longterm goal of restructuring the banking system after a period of ineffective credit growth, the government issued "Decision No. 2154" in 2012 accompanied by many essential reforms, which emphasises requirements for banks to boost the non-lending segments. In a sense, this orientation is at odds with regulatory changes in the postcrisis period implemented in the US and Europe, which forced banks to restrict noninterest activities (Chow \& Surti, 2011). The restriction stems from concerns about the downsides of diversification into non-lending activities on the banking systems' safety and soundness (Abedifar, Molyneux, \& Tarazi, 2018). For the Vietnamese banking

a Department of Finance, Banking University of Ho Chi Minh City, 36 Ton That Dam Street, Nguyen Thai Binh Ward, District 1, Ho Chi Minh City 700000, Vietnam. Email: dandv@buh.edu.vn 
industry's case, the issue becomes even more critical when the business shift could directly alter bank lending behaviour and indirectly drive economic growth. Theories show that decreased asymmetric information thanks to banking diversification may well support bank lending (Boot, 2000). In turn, lending activities could promote cross-selling products and boost non-interest revenue (Gallo, Apilado, \& Kolari, 1996). Besides, we need to comparatively clarify the cost-benefit trade-off between the two business categories, lending and non-interest segments. Given these contexts, the empirical reciprocal relationship between bank lending and non-interest activities, along with their comparative impacts on bank performance, is worthy of an in-depth analysis.

Many studies have been conducted to examine the effects of non-interest income on banks' financial structure and business performance. Accordingly, the works have shown important implications about standalone risks/systematic risks and key profitability indicators of banks, but reaching no consensus among conclusions (see section 2 for a review). The first common point of most studies is to primarily look into the financially developed markets where the banking industry has significant differences in scale, maturity and institutional environment compared to that in the developing markets (Ahamed, 2017; Meslier, Tacneng, \& Tarazi, 2014). Notably, in terms of the noninterest business lines' contribution to total return, the banking systems of developed countries proved to be superior (Dang, 2020; Doan, Lin, \& Doong, 2018). Another important detail is that previous studies have focused almost exclusively on performance analysis of non-interest income to reveal its premiums and discounts. Instead, they neglected the comparison with lending simultaneously to suggest a full trade-off pattern. In general, non-interest activities are approached through the total income perspective with the sum of fee-based income, trading income and other operating income; work focusing on disaggregate items is relatively scarce (Abedifar et al., 2018). In another strand of research on the lending/non-interest activities nexus, previous scholars carefully consider the association between non-interest income and typical components of lending, including net interest margins and lending rates (Lepetit, Nys, Rous, \& Tarazi, 2008; Nguyen, 2012). The concepts of such research are based on the fact that banks could use income sources to compensate for each other. However, the scale of loan portfolio relative to total assets, an important aspect of bank lending, is almost neglected in a reciprocal relationship with non-interest income.

Motivated by the stylised facts mentioned above, in this study we firstly analyse the reciprocal relationship between bank lending and fee-based income, and secondly examine the comparative effects of two segments on bank performance of the Vietnamese market. The Vietnamese banks earn their fee-based income from multiple freerisk activities such as service charges of loans/deposits transactions, commissions and insurance sales. Differently, the trading income comes from essential items consisting of trading securities, investment securities and foreign exchange transactions. The feebased income sources are stable but cover high fixed costs, while the trading income is significantly sensitive to market fluctuations and potentially leads to high volatility of income (Köhler, 2014). Also, fee-based income is thought to have a relationship with lending that does not only generate interest income in some cases (DeYoung \& Rice, 2004). Hence, the fee income share/lending ratio nexus is expected to provide insightful implications. We employ the system of equations approach with the three-stage least 
squares (3SLS) estimator, which could obtain efficient regressions for a reciprocal relationship. For bank performance analyses, we apply a rich set of alternative measures for bank profitability, risk-adjusted profits and bank risk inspired by previous works. These performance analyses are supported by the generalized method of moments (GMM) estimator for the dynamic panel.

The banking system of Vietnam also offers some characteristics that make it a favourable laboratory for our empirical analysis. As a transitional and fast-growing market, Vietnam is a typical representative of the important emerging economies, which do not attract much attention from academics on the topic. These markets are featured by the fact that bank lending is always a key indicator of the economy, and at the same time, non-interest income of the banking industry still accounts for a low proportion. Notably, the period of aggressive credit growth in 2007-2008 has caused significant changes and reshaped banking operations. Besides, Vietnamese banks are still weak and associated with a lack of experience and expertise when they have to pursue a larger span of business models. Thus, analysing a single market like Vietnam, based on the good advantage of a uniform environment, may gain a reference pattern for Vietnam and other emerging markets as well. ${ }^{1}$

This study contributes to the existing literature in several directions. As far as we know, our study is the first to investigate the reciprocal relationship between bank lending and non-interest income in the dimensions of lending ratio and fee-based income, using the 3SLS procedure for the simultaneous equations framework. The study also provides a rich set of performance measures, including bank profitability, riskadjusted profits and bank risk, thereby allowing a better comparison between lending and fee-based categories. Instead of focusing separately on each category to derive the cost-benefit implications like other studies, we prefer finding a lending-fee balance in the bank business strategy. Additionally, given that there exist few studies that exploit emerging economies, our research enriches the stream of research on the topic via the perspective of Vietnam.

\section{Previous Literature}

\subsection{The Reciprocal Relationship between Lending and Fee Income}

Though there exists very little empirical work about the reciprocal relationship between bank lending and fee income, there is some interesting theoretical literature that allows us to form predictions about the current relationship that we are exploring. The diversification into non-lending sectors helps banks expand their customer database and motivate more exposures to potential borrowers (Abedifar et al., 2018). Theories of financial intermediation indicate that informational advantages help banks overcome asymmetric information problems thanks to closer relationships with customers (Boot, 2000), which then improve credit quality through better supervision and monitoring. A credit relationship after previous non-credit transactions is found

1 For a clear overview of the Vietnamese financial market and the banking system, see Dang (2019a, 2019b), Nguyen and Nguyen (2018) and Vo (2018). 
to reduce the probability of borrower defaults (Puri, Rocholl, \& Steffen, 2011). In turn, when lending activities increase, banks themselves have more favourable conditions to promote cross-selling products and boost revenue from non-interest segments (Gallo et al., 1996). Based on the argument of DeYoung and Rice (2004), it is necessary to understand that banks also earn fee income from the traditional lending segment. For instance, payment services of banks in the US, which mainly contribute to the fee-based income source, are derived from lending activities. In sum, the arguments mentioned above imply a positive reciprocal relationship between lending and fee income.

Besides a potential positive link, existing documents also offer arguments that protect opposing predictions. DeYoung and Roland (2001) mentioned the lower switching costs of fee-based activities than those of lending. This nature leads banks to lend generously to customers to build long-term relationships. The strategy is more pronounced if banks have high expectations for increased fee income as a surplus in the future (Petersen \& Rajan, 1995). Developing these assumptions, Lepetit et al. (2008) used the "loss leaders" hypothesis to discuss bank behaviour. That is, banks could lower lending rates and reduce interest margins when they raise non-interest income; similarly, reducing lending rates could help attract customers and then increase noninterest revenue as compensation. Empirical evidence confirming the "loss leaders" hypothesis is exhibited in the study of Lepetit et al. (2008) and the subsequent work of Nguyen (2012), using the data of European banks. Given this context, a further step to consider the lending ratio, in addition to the lending rate and interest margin, is expected to shed new light supporting the "loss leaders" hypothesis.

\subsection{How Do Lending and Fee Income Drive Bank Performance?}

There has been a growing number of surveys on how non-interest income affects bank performance. Detailed reviews have been provided in previous studies such as those of Ahamed (2017), Doumpos, Gaganis and Pasiouras (2016) and Lee, Yang and Chang (2014). We therefore present a brief background to highlight the most critical understanding of the topic.

We begin with the innate differences between lending and non-interest activities. Regulators do not require banks to hold capital against the fee-based segments, which completely differs from the regulatory capital constraint on risky lending (DeYoung \& Roland, 2001). A good capitalisation level may make banks more reckless in investments (Demirgüç-Kunt \& Kane, 2002). Besides the difference in financial leverage, non-interest activities also require larger operating leverage than traditional lending (DeYoung \& Torna, 2013). From the perspective of business risk, spending more fixed costs puts great pressure on banks if they fail to cover such costs in the context that fee-based activities confront increasing competition from other institutions' substitute services. Another reason for the higher volatility of fee income is lower switching costs, as mentioned earlier, which greatly influence lending decisions and supervision (DeYoung \& Roland, 2001). Overall, the different nature of the two business lines has changed how they drive bank performance.

Banks are motivated by lending, a key performance evaluation indicator for bank managers (Acharya \& Naqvi, 2012). The increase in lending, however, in addition to the 
ambiguous benefits of profitability found (Fahlenbrach, Prilmeier, \& Stulz, 2018; Foos, Norden, \& Weber, 2010), leads to a high probability of associated risks. Biased selection and inadequate monitoring have undermined credit quality and then a loss for banks. The arguments have been proven in comprehensive studies on the impacts of lending behaviour on bank performance worldwide (Foos et al., 2010; Salas \& Saurina, 2002) and even Vietnam (Dang, 2019a).

The extensive literature looks into the motives of moving into the fee-based segment. From the theoretical view, banks could take advantage of the economies of scope through cross-selling chances and cost reduction with joint production (Claessens \& Klingebiel, 2001). Banks may thus improve their efficiency and profitability, as empirically indicated in developed markets (Calmès \& Théoret, 2010; Chiorazzo, Milani, \& Salvini, 2008; Elsas, Hackethal, \& Holzhäuser, 2010) and emerging counterparts (Ahamed, 2017; Meslier et al., 2014; Nguyen, Skully, \& Perera, 2012). According to diversification theory, banks expect to mitigate risks when diversifying into non-interest business lines. Abundant empirical analyses have previously supported the notion that an increase in non-interest income is accompanied by reduced risks (Gallo et al., 1996; Shim, 2013).

Despite the potential benefits of fee-based activities, the existing documents simultaneously provide conflicting views about the discounts of the business shift on bank performance. It is generally accepted that boosting non-interest activities leads to agency problems, which may somehow prioritise poor lines of business instead of better segments (Berger \& Ofek, 1995). Broadly, managers could sacrifice corporate values in exchange for their interests (Jensen, 1986). Many studies have found evidence in favour of the agency costs that destroy any upsides from the hypotheses of economies of scope and revenue diversification (DeYoung \& Torna, 2013; Laeven \& Levine, 2007; Williams, 2016). Mainly focusing on banks in the US and Europe, these studies have notably shown that higher shares of non-interest income are correlated with lower profitability, increased risks (standalone and systemic risks), and lower riskadjusted profits. Additionally, the volatile nature of non-interest income is often seen as a risk implication (DeYoung \& Roland, 2001; Stiroh, 2004).

\section{Methodology and Data}

\subsection{Methodology}

We first examine the reciprocal relationship between lending and fee-based income. To this end, we employ the simultaneous equation approach as follows:

$$
\begin{aligned}
& \text { Lending }_{i, t}=\alpha_{0}+\alpha_{1} \times \text { Fee }_{i, t}+\alpha_{2} \times \text { Control }_{i, t}+\varepsilon_{i, t} \\
& \text { Fee }_{i, t}=\alpha_{0}+\alpha_{1} \times \text { Lending }_{i, t}+\alpha_{2} \times \text { Control }_{i, t}+\varepsilon_{i, t}
\end{aligned}
$$

where $i$ denotes individual banks and $t$ denotes time dimension. Control is a vector of control variables and $\varepsilon_{i, t}$ is the error term. Lending captures lending activities, calculated by the ratio of gross customer loans divided by total assets. Fee represents fee-based 
income, measured by the ratio of net fee income to total operating income. ${ }^{2}$ As such, we have approached all two aspects of banking diversification measure, namely, the asset-based aspect and the income-based one (Elsas et al., 2010; Laeven \& Levine, 2007). The higher these ratios are, the more banks focus on lending or earning from fee-based services.

According to the theoretical and empirical literature, bank lending tends to be explained by critical bank-specific factors, including bank size, profitability and capitalisation. Under the "too big to fail" hypothesis, large banks may take more risks and grant more loans (Kim \& Sohn, 2017). For more profitable banks, they could comfortably reduce lending rates, supporting lending expansion (Mankiw, 1986). Regarding bank capitalisation, holding more equity capital enhances the risk-bearing capacity and encourages banks to make more loans (Coval \& Thakor, 2005). In the determinant analysis of fee-based income, inspired by previous studies, we integrate bank-level variables into the model specification, namely, bank size, net interest margin and credit risk. Theories suggest that banks with higher credit risk should focus on the non-lending segment for safety purposes, which could improve the fee income (Maudos \& Guevara, 2004). With the inclusion of the net interest margin, banks may price loans to stimulate the sales of non-traditional services, emphasising the loss-leader argument (Nguyen, 2012). Besides, the macroeconomic environment covering economic growth and inflation also plays an essential role in shaping profit-making behaviour. During an economic upturn, the market increases loan demands and requires more banking services (Behr, Foos, \& Norden, 2017). During inflationary periods, banks have to raise lending rates and service charges, which is likely to decrease lending and fee income (Adesina, 2019). For detailed definitions of control variables, see Table 1.

To estimate the system of equations simultaneously, we apply the 3SLS. The 3SLS procedure for the simultaneous equations framework could account for the endogeneity of both lending activities and fee income in the banking model. This technique is considered as the two-stage least squares (2SLS) version using the seemingly unrelated regression (SUR), thus it creates more efficient estimates than 2SLS (Zellner \& Theil, 1962) while incorporating the cross-equation correlations between unobserved disturbances.

After analysing the reciprocal relationship between lending and fee income, we further explore the impact of these two factors on bank performance. For the model specification, we approach the dynamic framework motivated by the extensive documents displaying the persistence of bank risk and return (Berger, Bonime, Covitz, \& Hancock, 2000; Delis \& Kouretas, 2011; Goddard, Molyneux, \& Wilson, 2004). The dynamic panel model is also widely applied in recent studies on bank performance/ non-interest income nexus (Abedifar et al., 2018; Lee et al., 2014; Meslier et al., 2014), containing one-period lagged dependent variables as follows:

$$
Y_{i, t}=\alpha_{0}+\alpha_{1} \times Y_{i, t-1}+\alpha_{2} \times \text { Lending }_{i, t}+\alpha_{3} \times \text { Fee }_{i, t}+\alpha_{4} \times \text { Control }_{i, t}+\varepsilon_{i, t}
$$

2 We also employ another alternative measure for fee-based income, calculated by the ratio of gross fee income to total average assets, to test the robustness of our results. The empirical analysis yields the same patterns. We do not report all of the results by this measure for the sake of brevity. 
where $Y_{i, t}$ is the performance measure for bank $i$ at time $t$. We take multiple measures for bank profitability (return on assets $-R O A$, return on equity $-R O E$ and net interest margin - NIM), risk-adjusted profits (ROAad and ROEad) and bank risk (loan loss provisions - LLP and non performing loan - NPL). For bank profitability, ROA (or ROE) is computed by the ratio of net return over total average assets (or total average equity); while NIM is the net interest margin, calculated by the net interest income divided by total average earning assets. For risk-adjusted profits, ROAad (or ROEad) is obtained by the ratio of $R O A$ (or $R O E$ ) over the standard deviation of $R O A$ (or $R O E$ ) for each bank over the whole period. And for bank risk, since we have no single definition and consensual calculation of bank risk, we choose to approach the credit risk which is the most important and typical type of bank risk. Moreover, the consideration of this risk category is relevant to the impact analysis of bank lending and fee-based activities of main interest. Hence, LLP and NPL are respectively measured by the ratio of loan loss provisions over total gross loans and the ratio of non-performing loans to total gross loans. Taken together, we have used a rich set of measures to capture bank performance. Additionally, based on previous literature, we also incorporate some control variables into the models, including bank capital equity, bank scale, economic growth and inflation. Theories also show that if banks gain more capital, they become more cautious with their operation, which can be translated into higher performance (Berger \& Bouwman, 2013). Larger banks can benefit from economies of scale, which should improve their return and reduce their risk exposures (Dang, 2019b). Finally, favourable economic conditions could improve bank profitability and minimise risks (Behr et al., 2017).

To perform the regression in the dynamic model, we employ the GMM estimator. The first version of GMM for the dynamic panel is applied by differencing all regressors, called the difference GMM, and using the lagged levels of the regressors as the instruments (Arellano \& Bond, 1991). The second version of GMM developed later employs two equations of the original equation in levels along with the transformed one in first differences and allows for the introduction of more instruments, known as the system GMM, and thus could dramatically enhance the efficiency of estimation (Arellano \& Bover, 1995; Blundell \& Bond, 1998). Therefore, we choose the system GMM estimator to gain better results. Besides, we further use the two-step and standard errors correction procedures following Windmeijer (2005) to curtail the downward bias in the system GMM estimator. The consistency of the GMM estimator is confirmed by two diagnostic tests, including the Hansen test of over-identifying restrictions for the validity of instruments and the Arellano-Bond test for detection of the second-order autocorrelation in first differences. ${ }^{3}$

\subsection{Data}

The study analyses the reciprocal relationship between bank lending and fee-based income and their comparative impacts on Vietnamese commercial banks' performance from 2007 to 2018. Our sample is an unbalanced panel with 349 observations from

3 We perform our regressions using the "xtabond2" syntax in Stata. For the detailed description of this command, see Roodman (2009). For the specific working of the system GMM estimator, see Arellano and Bover (1995) and Blundell and Bond (1998). 
30 commercial banks, accounting for over $95 \%$ of the Vietnamese banking system's total assets. Hence, the bank-specific data could well represent the population of the banking system in Vietnam. To obtain the target sample, we manually collect data from the annual financial reports published at each bank's website. Besides, we extract macroeconomic data from the World Development Indicators of the World Bank.

We present the descriptive summaries of variables in Table 1 . Notably, bank-level variables are winsorized at $2.5 \%$ and $97.5 \%$ to mitigate the effects of extreme outliers. Bank lending ratio is $53.99 \%$ on average, a relatively higher value compared to that in other developed economies (see Abedifar et al., 2018; Hidayat, Kakinaka, \& Miyamoto, 2012 for a comparison); meanwhile, the average fee-based income share is only $6.64 \%$, which is much lower than that in other markets despite efforts to increase this income source recently (see Doan et al., 2018; Lepetit et al., 2008 for a comparison as well). In addition, the remaining statistical values show that Vietnamese banks have divergent operation performance and financial structures as illustrated by the gaps between percentiles of measures.

The correlation coefficient matrix for pairs of variables is presented in Table 2. The matrix completes two primary tasks. First, through the small values of correlation coefficients between variables (except for variables measuring the same aspect, e.g.,

Table 1. Summary statistics

\begin{tabular}{lrrrrrrrr}
\hline Variables & Obs. & Std. Dev. & Mean & 10th & 25th & Median & 75th & 90th \\
\hline Lending & 349 & 13.24 & 53.99 & 35.49 & 44.03 & 55.42 & 64.76 & 70.64 \\
Fee & 349 & 5.86 & 6.64 & 0.26 & 2.15 & 5.36 & 9.63 & 14.87 \\
ROA & 349 & 0.58 & 0.83 & 0.11 & 0.39 & 0.73 & 1.21 & 1.66 \\
ROE & 349 & 6.15 & 8.80 & 1.00 & 4.17 & 7.88 & 12.79 & 17.89 \\
NIM & 349 & 1.12 & 2.79 & 1.53 & 2.00 & 2.74 & 3.47 & 4.29 \\
ROAad & 349 & 1.44 & 1.89 & 0.19 & 0.68 & 1.78 & 2.68 & 3.66 \\
ROEad & 349 & 1.64 & 2.05 & 0.21 & 0.82 & 1.88 & 2.87 & 3.76 \\
LLP & 349 & 0.35 & 0.68 & 0.29 & 0.47 & 0.61 & 0.79 & 1.13 \\
NPL & 305 & 1.38 & 2.22 & 0.70 & 1.28 & 2.07 & 2.71 & 3.87 \\
Equity & 349 & 5.45 & 10.43 & 5.48 & 6.68 & 8.78 & 12.60 & 17.91 \\
Size & 349 & 1.27 & 31.90 & 30.31 & 30.88 & 31.95 & 32.80 & 33.62 \\
GDP & 349 & 0.63 & 6.17 & 5.40 & 5.42 & 6.21 & 6.68 & 7.08 \\
Inflation & 349 & 6.26 & 8.07 & 3.24 & 3.52 & 6.59 & 9.09 & 18.67 \\
\hline
\end{tabular}

Note: The table displays the descriptive statistics of variables. All variables are presented in percentage (with the exception of the ROAad, ROEad and Size variables) and computed as follows. Lending captures bank lending activities, calculated by gross customer loans divided by total assets. Fee captures bank fee-based income, measured by the ratio of net fee income to total operating income. ROA $(R O E)$ proxies bank profitability, computed by the ratio of net return over total average assets (total average equity). NIM is the net interest margin, calculated by the net interest income divided by total average earning assets. ROAad (ROEad) is the risk-adjusted bank profitability, obtained by the ratio of ROA (ROE) over the standard deviation of ROA (ROE). LLP and NPL are the proxies for bank credit risk, respectively measured by the ratio of loan loss provisions over total gross loans and the ratio of non-performing loans to total gross loans. Equity captures the ratio of equity over total assets. Size is calculated by the natural logarithm of total assets. GDP denotes the annual growth rate of GDP. Inflation is the rate of annual inflation. 
Bank Performance and the Relationship between Lending and Fee-based Activities in an Emerging Market

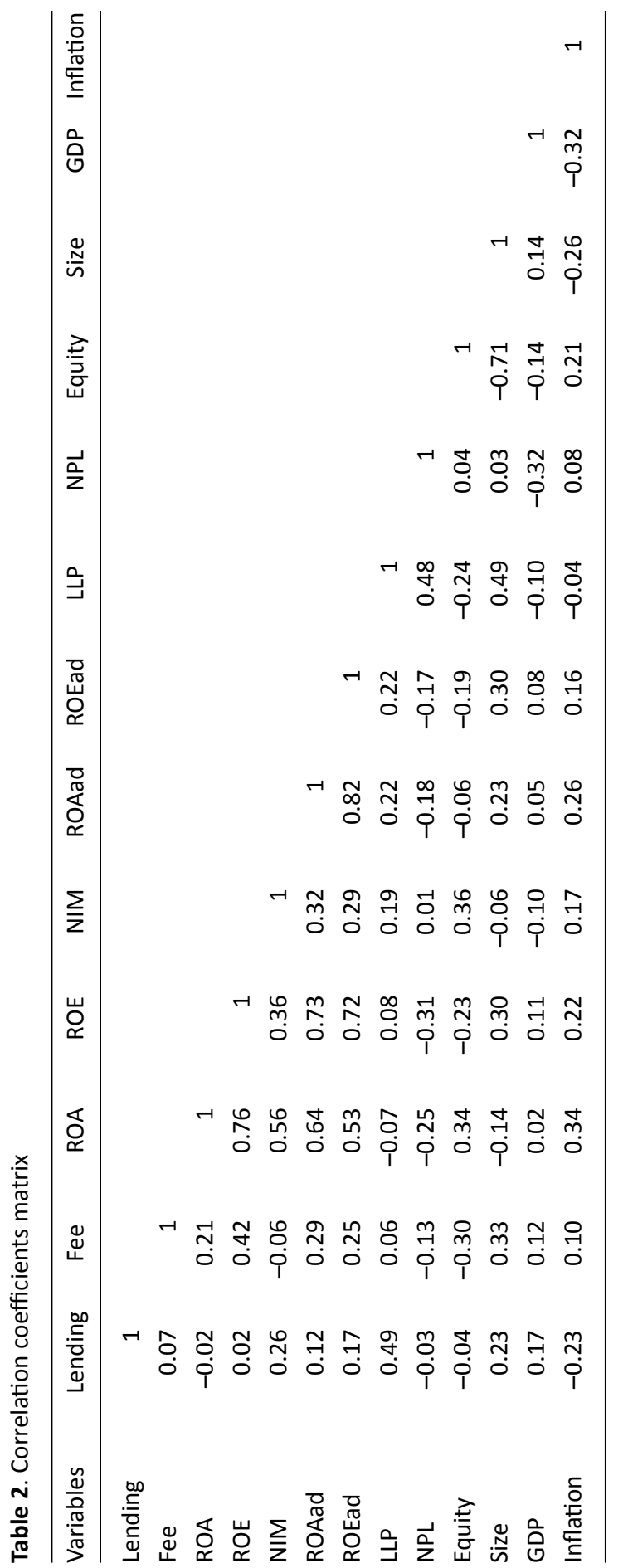


$R O A$ and $R O E$ ), we could ensure the absence of severe multicollinearity problem in the regression models, which is also confirmed by the value of the variance inflation factor. Second, preliminary correlations between variables of interest are displayed. We further need regression tests to achieve the research objectives.

\section{Results and Discussion}

\subsection{How Do Lending and Fee Income Influence Each Other?}

The first set of estimation results explores the reciprocal relationship between lending and fee income, as presented in Table 3. If the "loss leader" hypothesis could apply to the Vietnamese banking industry, we expect to find an inverse relationship. We perform regressions with alternative groups of control variables to test the sensitivity of estimation results, based on the mechanism of gradually removing the lower significant variables from the models.

Table 3. Relationship between lending and fee income

\begin{tabular}{|c|c|c|c|c|c|c|}
\hline Regressor & (1) Lending & (2) Fee & (3) Lending & (4) Fee & (5) Lending & (6) Fee \\
\hline Fee & $\begin{array}{l}-5.175^{* * *} \\
(1.552)\end{array}$ & & $\begin{array}{l}-3.556^{* * *} \\
(0.955)\end{array}$ & & $\begin{array}{l}-3.200^{* * *} \\
(0.873)\end{array}$ & \\
\hline Lending & & $\begin{array}{c}-0.638 \\
(0.409)\end{array}$ & & $\begin{array}{l}-0.699 * * * \\
(0.232)\end{array}$ & & $\begin{array}{l}-0.753^{* * *} \\
(0.222)\end{array}$ \\
\hline Equity & $\begin{array}{c}-0.516 \\
(0.508)\end{array}$ & & & & & \\
\hline ROA & $\begin{array}{l}11.086^{* *} \\
(4.975)\end{array}$ & & $\begin{array}{l}7.740 * * * \\
(2.970)\end{array}$ & & $\begin{array}{l}7.794^{* * *} \\
(3.005)\end{array}$ & \\
\hline Size & $\begin{array}{l}10.483^{* * *} \\
(2.480)\end{array}$ & $\begin{array}{l}2.058^{* * *} \\
(0.636)\end{array}$ & $\begin{array}{l}8.869 * * * \\
(2.110)\end{array}$ & $\begin{array}{l}3.261^{* * *} \\
(0.647)\end{array}$ & $\begin{array}{l}8.249 * * * \\
(1.806)\end{array}$ & $\begin{array}{l}3.663^{* * *} \\
(0.771)\end{array}$ \\
\hline NIM & & $\begin{array}{c}1.697 \\
(1.173)\end{array}$ & & $\begin{array}{l}2.064^{* * *} \\
(0.949)\end{array}$ & & $\begin{array}{l}1.979 * * * \\
(0.821)\end{array}$ \\
\hline LLP & & $\begin{array}{c}6.974 \\
(7.586)\end{array}$ & & & & \\
\hline GDP & $\begin{array}{c}5.654^{*} \\
(2.972)\end{array}$ & $\begin{array}{c}3.217 \\
(1.976)\end{array}$ & $\begin{array}{l}4.707^{* *} \\
(2.175)\end{array}$ & $\begin{array}{l}2.778^{* * *} \\
(1.101)\end{array}$ & & \\
\hline Inflation & $\begin{array}{c}0.554 \\
(0.401)\end{array}$ & $\begin{array}{c}-0.033 \\
(0.205)\end{array}$ & $\begin{array}{c}0.255 \\
(0.274)\end{array}$ & $\begin{array}{c}-0.049 \\
(0.137)\end{array}$ & & \\
\hline Observations & 349 & 349 & 349 & 349 & 349 & 349 \\
\hline R-squared & 0.635 & 0.672 & 0.691 & 0.675 & 0.618 & 0.637 \\
\hline
\end{tabular}

Note: The table presents the empirical results for the reciprocal relationship between bank lending and fee income, obtained by the 3SLS approach. Standard errors are shown in parentheses. ***,** and $*$ denote the $1 \%, 5 \%$ and $10 \%$ significant levels, respectively. We run separate pairs of regressions, presented in each group of two adjacent columns (including 1 and 2, 3 and 4, 5 and 6). 
The estimation results show a negative reciprocal relationship between bank lending and fee-based income. More precisely, the higher levels of fee income are associated with decreased bank lending ratio, while increased bank lending ratio is correlated with lower levels of fee income. It should be noted that the reverse impact of fee income on bank lending is found to be statistically significant at $1 \%$ level in all regressions, while the statistically significant effect of lending on fee income is observed in two regressions (columns 4 and 6) after the removal of insignificant control variables. In terms of economic significance, the findings are important as well. Taking column 3 for example, we could refer that an increase of $1 \%$ in fee-based income share tends to reduce bank lending ratio by $3.55 \%$, given the average ratio of loans to assets is $53.99 \%$; for column 4 , a $1 \%$ increase in lending activities could lead to a decrease in fee-based income share by $0.69 \%$, given the mean value of fee income share is $6.64 \%$.

In related studies, Lepetit et al. (2008) and Nguyen (2012) revealed an inverse relationship between non-interest activities and two critical dimensions of bank lending behaviour, namely, net interest margins and lending rates. With the inverse reciprocal relationship between fee income and lending ratio found, we add complementary evidence for the "loss leaders" hypothesis that prior scholars have employed to interpret the non-interest income/bank lending nexus. Vietnamese banks have flexibly coordinated the financial services provided to customers. In some detail, they may lower the fee charged to attract customers for better lending relationships, and when customers request more loans, the banks are willing to reduce their service prices. The finding is important to explain the profit-making behaviour of the banking sector.

\subsection{The Influence of Lending and Fee Income on Bank Performance}

With our model specification 3, we investigate how bank lending and fee income affect bank performance. For each measure of bank performance, we alternatively perform regressions with and without control variables to check the robustness of our estimation results. ${ }^{4}$ The Hansen test results do not lead to the rejection of the null hypothesis that the employed instruments are not correlated with the residuals. Based on the results of the Arellano-Bond test, we also do not reject the null hypothesis that the first difference residuals exhibit no autocorrelation. Hence, we confirm the validity of the instruments and the absence of second-order autocorrelation. Besides, the significance in both statistical and economic aspects of the coefficients on lagged dependent variables supports the application of the dynamic GMM estimator. Overall, we have the confidence to use the estimation results in all model specifications for decision making. We first begin with Table 4, which displays the estimation results for the profitability measures, including return on assets (columns 1 and 2), return on equity (columns 3 and 4), and net interest margin (columns 5 and 6).

Bank lending measured by the ratio of loans to assets is found to have a positive and significant impact on net interest margin at the $5 \%$ level, but no statistically

4 We also run regressions via the full set of control variables plus either bank lending or fee income to ensure our results' robustness. The patterns of interest always remain unchanged regardless of the alternative combination of variables. 
Table 4. Estimation results for the determinants of bank profitability

\begin{tabular}{|c|c|c|c|c|c|c|}
\hline Regressor & (1) ROA & (2) ROA & (3) ROE & (4) ROE & (5) NIM & (6) NIM \\
\hline $\mathrm{ROA}_{\mathrm{t}-1}$ & $\begin{array}{l}0.547^{* * *} \\
(0.088)\end{array}$ & $\begin{array}{l}0.502^{* * *} \\
(0.096)\end{array}$ & & & & \\
\hline $\mathrm{ROE}_{\mathrm{t}-1}$ & & & $\begin{array}{l}0.499 * * * \\
(0.096)\end{array}$ & $\begin{array}{l}0.592^{* * *} \\
(0.091)\end{array}$ & & \\
\hline $\mathrm{NIM}_{\mathrm{t}-1}$ & & & & & $\begin{array}{l}0.503^{* * *} \\
(0.096)\end{array}$ & $\begin{array}{l}0.547^{* * *} \\
(0.098)\end{array}$ \\
\hline Lending & $\begin{array}{c}0.001 \\
(0.002)\end{array}$ & $\begin{array}{c}0.000 \\
(0.003)\end{array}$ & $\begin{array}{c}0.015 \\
(0.027)\end{array}$ & $\begin{array}{c}0.010 \\
(0.026)\end{array}$ & $\begin{array}{l}0.014^{* *} \\
(0.006)\end{array}$ & $\begin{array}{c}0.022^{* *} \\
(0.010)\end{array}$ \\
\hline Fee & $\begin{array}{l}0.012^{* *} \\
(0.006)\end{array}$ & $\begin{array}{l}0.014^{* *} \\
(0.007)\end{array}$ & $\begin{array}{l}0.323^{* * *} \\
(0.090)\end{array}$ & $\begin{array}{l}0.248^{* * *} \\
(0.096)\end{array}$ & $\begin{array}{c}-0.013 \\
(0.010)\end{array}$ & $\begin{array}{c}-0.023 * \\
(0.013)\end{array}$ \\
\hline Equity & & $\begin{array}{c}0.019 \\
(0.012)\end{array}$ & & $\begin{array}{c}-0.182^{*} \\
(0.097)\end{array}$ & & $\begin{array}{c}-0.056 \\
(0.088)\end{array}$ \\
\hline Size & & $\begin{array}{c}0.035 \\
(0.036)\end{array}$ & & $\begin{array}{c}-0.164 \\
(0.521)\end{array}$ & & $\begin{array}{c}-0.180 \\
(0.274)\end{array}$ \\
\hline GDP & & $\begin{array}{c}0.097^{* *} \\
(0.040)\end{array}$ & & $\begin{array}{l}0.889 * * \\
(0.407)\end{array}$ & & $\begin{array}{c}0.154 \\
(0.125)\end{array}$ \\
\hline Inflation & & $\begin{array}{c}0.012^{*} \\
(0.007)\end{array}$ & & $\begin{array}{c}0.039 \\
(0.068)\end{array}$ & & $\begin{array}{l}0.051^{* * *} \\
(0.011)\end{array}$ \\
\hline Observations & 319 & 319 & 319 & 319 & 319 & 319 \\
\hline Number of groups & 30 & 30 & 30 & 30 & 30 & 30 \\
\hline Number of instruments & 23 & 26 & 23 & 26 & 23 & 26 \\
\hline $\operatorname{AR}(1)$ (p-value) & $\begin{array}{l}-2.62 \\
(0.009)\end{array}$ & $\begin{array}{l}-2.68 \\
(0.007)\end{array}$ & $\begin{array}{l}-3.12 \\
(0.002)\end{array}$ & $\begin{array}{l}-3.26 \\
(0.001)\end{array}$ & $\begin{array}{l}-3.16 \\
(0.002)\end{array}$ & $\begin{array}{l}-3.32 \\
(0.001)\end{array}$ \\
\hline $\operatorname{AR}(2)$ (p-value) & $\begin{array}{l}1.13 \\
(0.259)\end{array}$ & $\begin{array}{l}1.29 \\
(0.196)\end{array}$ & $\begin{array}{l}1.65 \\
(0.100)\end{array}$ & $\begin{array}{l}1.44 \\
(0.149)\end{array}$ & $\begin{array}{l}-1.89 \\
(0.059)\end{array}$ & $\begin{array}{l}-1.03 \\
(0.304)\end{array}$ \\
\hline Hansen test ( $p$-value) & $\begin{array}{c}22.70 \\
(0.251)\end{array}$ & $\begin{array}{c}23.37 \\
(0.221)\end{array}$ & $\begin{array}{c}22.92 \\
(0.241)\end{array}$ & $\begin{array}{c}25.33 \\
(0.150)\end{array}$ & $\begin{array}{l}26.85 \\
(0.108)\end{array}$ & $\begin{array}{c}23.97 \\
(0.156)\end{array}$ \\
\hline
\end{tabular}

Note: The table presents the empirical results for determinants of bank profitability, measured by $R O A, R O E$ and NIM, using the two-step system GMM in the dynamic panel model. All variables are defined in Table 1 . The Hansen test is to verify the validity of the used instruments, the Arellano-Bond test is to test the autocorrelation of the first difference residuals. $* * *, * *$ and ${ }^{*}$ denote the $1 \%, 5 \%$ and $10 \%$ significant levels, respectively.

significant influence on the profitability measures $R O A$ and $R O E$. For the positive impact on the net interest margin itself, the economic significance is also reasonable. Taking column 6 for example, a one standard deviation increase in lending (13.24\%) leads to a rise in NIM by $0.29 \%$, given the mean value of $N I M$ is $2.79 \%$. In sharp contrast, the estimation results show that fee-based income has significantly positive impacts on both return on assets and return on equity at the lowest level of $5 \%$, but no significant effect on the NIM variable. Based on results in column 2 (or column 4), we could 
observe that an increase of one standard deviation in fee income share (5.86\%) is likely to increase $R O A$ by $0.08 \%$ (or $R O E$ by $1.45 \%$ ). These findings are not inconsequential if considering that the mean value of $R O A$ is $0.83 \%$ (or $R O E$ is $8.80 \%$ ).

Moving on to the section of risk-adjusted profits, the estimation results shown in Table 5 highlight the positive and significant influence of fee income on two risk-adjusted measures of ROA and ROE. The statistical significance levels are slightly reduced when adding control variables into the model specifications, but in general our coefficients still hold economically reasonable magnitudes. Unlike non-lending segments, bank lending does not show any statistically significant impact on risk-adjusted profits.

Table 5. Estimation results for the determinants of risk-adjusted profitability

\begin{tabular}{|c|c|c|c|c|}
\hline Regressor & (1) ROAad & (2) ROAad & (3) ROEad & (4) ROEad \\
\hline $\operatorname{ROAad}_{\mathrm{t}-1}$ & $\begin{array}{l}0.390^{* * *} \\
(0.012)\end{array}$ & $\begin{array}{l}0.551^{* * *} \\
(0.106)\end{array}$ & & \\
\hline ROEad $_{t-1}$ & & & $\begin{array}{l}0.370^{* * *} \\
(0.093)\end{array}$ & $\begin{array}{l}0.491^{* * *} \\
(0.093)\end{array}$ \\
\hline Lending & $\begin{array}{c}0.007 \\
(0.008)\end{array}$ & $\begin{array}{c}0.007 \\
(0.008)\end{array}$ & $\begin{array}{c}0.010 \\
(0.011)\end{array}$ & $\begin{array}{c}0.009 \\
(0.009)\end{array}$ \\
\hline Fee & $\begin{array}{l}0.047^{* *} \\
(0.019)\end{array}$ & $\begin{array}{c}0.023 \\
(0.019)\end{array}$ & $\begin{array}{l}0.063^{* * *} \\
(0.024)\end{array}$ & $\begin{array}{c}0.044^{*} \\
(0.024)\end{array}$ \\
\hline Equity & & $\begin{array}{c}0.026 \\
(0.023)\end{array}$ & & $\begin{array}{c}-0.048 \\
(0.026)\end{array}$ \\
\hline Size & & $\begin{array}{c}0.229 * * \\
(0.106)\end{array}$ & & $\begin{array}{c}0.031 \\
(0.149)\end{array}$ \\
\hline GDP & & $\begin{array}{c}0.159 * \\
(0.090)\end{array}$ & & $\begin{array}{c}0.141 \\
(0.094)\end{array}$ \\
\hline Inflation & & $\begin{array}{c}0.027 * \\
(0.014)\end{array}$ & & $\begin{array}{c}0.022 \\
(0.017)\end{array}$ \\
\hline Number of observations & 319 & 319 & 319 & 319 \\
\hline Number of groups & 30 & 30 & 30 & 30 \\
\hline Number of instruments & 23 & 27 & 23 & 27 \\
\hline $\operatorname{AR}(1)$ (p-value) & $\begin{array}{l}-2.87 \\
(0.004)\end{array}$ & $\begin{array}{l}3.30 \\
(0.001)\end{array}$ & $\begin{array}{l}-3.00 \\
(0.003)\end{array}$ & $\begin{array}{l}-3.36 \\
(0.001)\end{array}$ \\
\hline $\operatorname{AR}(2)$ (p-value) & $\begin{array}{l}1.10 \\
(0.270)\end{array}$ & $\begin{array}{l}1.16 \\
(0.244)\end{array}$ & $\begin{array}{l}1.40 \\
(0.162)\end{array}$ & $\begin{array}{l}1.20 \\
(0.231)\end{array}$ \\
\hline Hansen test ( $p$-value) & $\begin{array}{c}24.29 \\
(0.185)\end{array}$ & $\begin{array}{c}26.34 \\
(0.121)\end{array}$ & $\begin{array}{c}25.79 \\
(0.136)\end{array}$ & $\begin{array}{c}25.93 \\
(0.132)\end{array}$ \\
\hline
\end{tabular}

Note: The table presents the empirical results for determinants of risk-adjusted profitability, measured by ROAad and ROEad, using the two-step system GMM in the dynamic panel model. All variables are defined in Table 1. The Hansen test is to verify the validity of the used instruments, the Arellano-Bond test is to test the autocorrelation of the first difference residuals. ${ }^{* * *}, * *$ and ${ }^{*}$ denote the $1 \%, 5 \%$ and $10 \%$ significant levels, respectively. 
Our findings reveal the upsides of fee-based activities in terms of improving overall profitability and risk-adjusted profits, in line with previous conclusions by Meslier et al. (2014) and Ahamed (2017) who were interested in emerging markets. From the theoretical perspective, banks could take advantage of the economies of scope through cross-selling chances and cost reduction with joint production (Claessens \& Klingebiel, 2001). In contrast, despite the significant contribution to better net interest margins, lending activities do not affect the overall profits measured by return on assets/equity. Banks tend to charge a larger margin that could compensate for credit risk predicted when they specialise in lending (Maudos \& De Guevara, 2004). It is likely that, however, the risk aspect outweighs its benefits.

Besides bank profitability measures, we also examine the impacts of lending ratio and fee income share on bank risk in the form of credit risk. In Table 6, we exhibit our estimation results in the functions of loan loss provisions (columns 1 and 2) and nonperforming loans (columns 3 and 4). Once again, our results indicate the differences between the influential patterns of two factors of interest. Accordingly, bank lending is found to have a positive and significant impact on credit risk, while we find no evidence of any statistically significant impact of the fee income variable. The impact of a high lending ratio on credit risk is confirmed in the analysis of the loan loss provisions variable, but not the non-performing loans ratio. This inconsistency of alternative measures could be attributed to the missing observations of the non-performing loans ratio.

The extra involvement in the lending segment is likely to place banks at higher risks, consistent with the majority of existing documents (Foos et al., 2010; Salas \& Saurina, 2002) and what happened to the Vietnamese banking industry (Dang, 2019a). When increasing the scale of loan portfolios, banks have to relax collateral requirements, ease credit standards and disperse monitoring resources. Besides, the gain from net interest margins is neutralised by the higher level of credit risks when banks focus more on lending activities, thus confirming the insignificant effects on overall profits proxied by return on assets/equity. Different from lending activities, the increase in fee-based income does not offer any evidence in favour of a significant influence on credit risk, which accords with the prior work of Abedifar et al. (2018). However, it seems that banks with high fee income share underestimate the delegate monitoring role of financial intermediation when establishing a long-term relationship with their customers (DeYoung \& Roland, 2001). This mechanism neutralises the potential advantages of fee-based activities.

\section{Conclusions}

Facing a competitive trend in the increasingly narrow credit markets, banks are forced to diversify their business lines and expand non-interest income sources. This fact attracts numerous attention and then in-depth analyses of scholars. Prior studies have revealed the cost-benefit feature of banks as they diversify into non-lending segments; besides, there are well-analysed assessments on the separate effects of traditional lending on banks. Unlike those works, this study focuses on the comparative influences of fee-based income and lending on bank performance, highly expecting to clarify a reasonable lending-fee balance for market participants and regulators. Furthermore, a 
Table 6. Estimation results for the determinants of bank risk

\begin{tabular}{|c|c|c|c|c|}
\hline Regressor & (1) LLP & (2) LLP & (3) NPL & (4) NPL \\
\hline $\operatorname{LLP}_{\mathrm{t}-1}$ & $\begin{array}{l}0.678^{* * *} \\
(0.095)\end{array}$ & $\begin{array}{l}0.634^{* * *} \\
(0.092)\end{array}$ & & \\
\hline$N P L_{t-1}$ & & & $\begin{array}{l}0.380^{* * *} \\
(0.098)\end{array}$ & $\begin{array}{l}0.342^{* * *} \\
(0.100)\end{array}$ \\
\hline Lending & $\begin{array}{l}0.005^{* * *} \\
(0.001)\end{array}$ & $\begin{array}{l}0.006^{* * *} \\
(0.001)\end{array}$ & $\begin{array}{c}-0.002 \\
(0.009)\end{array}$ & $\begin{array}{c}0.004 \\
(0.010)\end{array}$ \\
\hline Fee & $\begin{array}{c}0.003 \\
(0.003)\end{array}$ & $\begin{array}{c}0.000 \\
(0.004)\end{array}$ & $\begin{array}{c}-0.007 \\
(0.019)\end{array}$ & $\begin{array}{c}-0.006 \\
(0.022)\end{array}$ \\
\hline Equity & & $\begin{array}{c}0.004 \\
(0.004)\end{array}$ & & $\begin{array}{c}0.051^{* *} \\
(0.023)\end{array}$ \\
\hline Size & & $\begin{array}{c}0.050^{*} \\
(0.025)\end{array}$ & & $\begin{array}{c}0.159 \\
(0.151)\end{array}$ \\
\hline GDP & & $\begin{array}{c}-0.048^{* *} \\
(0.021)\end{array}$ & & $\begin{array}{c}-0.312^{* *} \\
(0.141)\end{array}$ \\
\hline Inflation & & $\begin{array}{c}0.006^{* *} \\
(0.003)\end{array}$ & & $\begin{array}{c}0.038^{* *} \\
(0.016)\end{array}$ \\
\hline Number of observations & 319 & 319 & 269 & 269 \\
\hline Number of groups & 30 & 30 & 30 & 30 \\
\hline Number of instruments & 23 & 27 & 23 & 27 \\
\hline $\operatorname{AR}(1)$ (p-value) & $\begin{array}{l}-3.14 \\
(0.002)\end{array}$ & $\begin{array}{l}-3.34 \\
(0.001)\end{array}$ & $\begin{array}{l}-2.23 \\
(0.026)\end{array}$ & $\begin{array}{l}-2.28 \\
(0.023)\end{array}$ \\
\hline $\operatorname{AR}(2)$ (p-value) & $\begin{array}{c}0.43 \\
(0.664)\end{array}$ & $\begin{array}{c}0.62 \\
(0.534)\end{array}$ & $\begin{array}{l}-1.72 \\
(0.086)\end{array}$ & $\begin{array}{l}-1.33 \\
(0.184)\end{array}$ \\
\hline Hansen test ( $p$-value) & $\begin{array}{c}21.20 \\
(0.326)\end{array}$ & $\begin{array}{c}21.01 \\
(0.336)\end{array}$ & $\begin{array}{c}27.50 \\
(0.094)\end{array}$ & $\begin{array}{c}26.23 \\
(0.124)\end{array}$ \\
\hline
\end{tabular}

Note: The table presents the empirical results for determinants of bank risk, measured by LLP and NPL, using the two-step system GMM in the dynamic panel model. All variables are defined in Table 1. The Hansen test is to verify the validity of the used instruments, the Arellano-Bond test is to test the autocorrelation of the first difference residuals. $* * *, * *$ and $*$ denote the $1 \%, 5 \%$ and $10 \%$ significant levels, respectively.

reciprocal relationship between lending and fee income is also investigated to define bank profit-making behaviour.

Using data from 2007 to 2018 of Vietnamese banks, we exhibit important results. We find an inverse reciprocal relationship between bank lending ratio and fee-based income share, thereby contributing to the "loss leaders" hypothesis and prior findings on the nexus between non-interest income and interest margin/lending rate (Lepetit et al., 2008, Nguyen, 2012). The results are robust to the system of simultaneous equations using the 3SLS with different sets of variables. For the bank performance analysis, we use the dynamic panel models with the system GMM estimator and find evidence in 
favour of the benefits of the economies of scope along with differences in the riskreturn mechanism of lending and fee-based activities. Specifically, fee income is found to positively affect returns on assets, returns on equity and risk-adjusted profits. On the contrary, concentrating more on lending only boosts net interest margins but contains more risks shown by higher loss provision levels. The natural differences between the two types of activities have created an interesting risk-return trade-off pattern.

The study provides some implications. From the commercial perspective, banks should be fully aware of the cost-benefit feature of lending and fee-based activities to determine better strategies, given our findings that bank lending proposes a clearcut risk-return trade-off and fee-based activities indicate the benefits associated with the overall profitability of the bank. Banks could also take advantage of the inverse reciprocal relationship between the two groups of activities to actively navigate income flows and business targets. From the policy perspective, regulators may encourage banks to design a combined business model that prioritises harmony across segments. Such a model should ensure both the safety of the banking system and the funding supply for the economy, especially in markets that highly value lending and initially restructure their income portfolio.

\section{References}

Abedifar, P., Molyneux, P., \& Tarazi, A. (2018). Non-interest income and bank lending. Journal of Banking \& Finance, 87(February), 411-426. https://doi.org/10.1016/j.jbankfin.2017.11.003

Acharya, V., \& Naqvi, H. (2012). The seeds of a crisis: A theory of bank liquidity and risk taking over the business cycle. Journal of Financial Economics, 106(2), 349-366. https://doi. org/10.1016/j.jfineco.2012.05.014

Adesina, K.S. (2019). Basel III liquidity rules: The implications for bank lending growth in Africa. Economic Systems, 43(2), 100688. https://doi.org/10.1016/j.ecosys.2018.10.002

Ahamed, M.M. (2017). Asset quality, non-interest income, and bank profitability: Evidence from Indian banks. Economic Modelling, 63(June), 1-14. https://doi.org/10.1016/j. econmod.2017.01.016

Arellano, M., \& Bond, S. (1991). Some tests of specification for panel data: Monte-Carlo evidence and an application to employment equations. Review of Economic Studies, 58(2), 277-297. https://doi.org/10.2307/2297968

Arellano, M., \& Bover, O. (1995). Another look at the instrumental variable estimation of errorcomponents models. Journal of Econometrics, 68(1), 29-51. https://doi.org/10.1016/03044076(94)01642-D

Behr, P., Foos, D., \& Norden, L. (2017). Cyclicality of SME lending and government involvement in banks. Journal of Banking \& Finance, 77(April), 64-77. https://doi.org/10.1016/j.jbankfin. 2017.01.010

Berger, A.N., \& Bouwman, C.H.S. (2013). How does capital affect bank performance during financial crises? Journal of Financial Economics, 109(1), 146-176. https://doi.org/10.1016/j. jfineco.2013.02.008

Berger, A.N., Bonime, S.D., Covitz, D.M., \& Hancock, D. (2000). Why are bank profits so persistent? The roles of product market competition, informational opacity, and regional/ macroeconomic shocks. Journal of Banking \& Finance, 24(7), 1203-1235. https://doi. org/10.1016/S0378-4266(99)00124-7

Berger, P.G., \& Ofek, E. (1995). Diversification's effect on firm value. Journal of Financial Economics, 37(1), 39-65. https://doi.org/10.1016/0304-405X(94)00798-6 
Blundell, R., \& Bond, S. (1998). Initial conditions and moment restrictions in dynamic panel data models. Journal of Econometrics, 87(1), 115-143. https://doi.org/10.1016/S03044076(98)00009-8

Boot, A.W.A. (2000). Relationship banking: What do we know? Journal of Financial Intermediation, 9(1), 7-25. https://doi.org/10.1006/jfin.2000.0282

Calmès, C., \& Théoret, R. (2010). The impact of off-balance-sheet activities on banks returns: An application of the ARCH-M to Canadian data. Journal of Banking \& Finance, 34(7), 17191728. https://doi.org/10.1016/j.jbankfin.2010.03.017

Chiorazzo, V., Milani, C., \& Salvini, F. (2008). Income diversification and bank performance: Evidence from Italian banks. Journal of Financial Services Research, 33(3), 181-203. https:// doi.org/10.1007/s10693-008-0029-4

Chow, J.T.S., \& Surti, J.. (2011). Making banks safer: Can Volcker and Vickers do it? (IMF Working Paper, WP/11/236). Washington, DC: International Monetary Fund. Retrieved from https:// www.imf.org/external/pubs/ft/wp/2011/wp11236.pdf

Claessens, S., \& Klingebiel, D. (2001). Competition and scope of activities in financial services. The World Bank Research Observer, 16(1), 19-40. https://doi.org/10.1093/wbro/16.1.19

Coval, J.D., \& Thakor, A.V. (2005). Financial intermediation as a beliefs-bridge between optimists and pessimists. Journal of Financial Economics, 75(3), 535-569. https://doi.org/10.1016/j. jineco.2004.02.005

Dang, V.D. (2019a). The effects of loan growth on bank performance: Evidence from Vietnam. Management Science Letters, 9, 899-910. https://doi.org/10.5267/j.msl.2019.2.012

Dang, V.D. (2019b). The risk-return trade-off of liquidity positions: Evidence from Vietnamese banking system. International Journal of Monetary Economics and Finance, 12(5), 390-406. https://doi.org/10.1504/IJMEF.2019.102954

Dang, V.D. (2020). Do non-traditional banking activities reduce bank liquidity creation? Evidence from Vietnam. Research in International Business and Finance, 54(December), 101257. https://doi.org/10.1016/j.ribaf.2020.101257

Delis, M.D., \& Kouretas, G.P. (2011). Interest rates and bank risk-taking. Journal of Banking \& Finance, 35(4), 840-855. https://doi.org/10.1016/j.jbankfin.2010.09.032

Demirgüç-Kunt, A., \& Kane, E.J. (2002). Deposit insurance around the globe: Where does it work? Journal of Economic Perspectives, 16(2), 175-195. https://doi.org/10.1257/0895330027319

DeYoung, R., \& Rice, T. (2004). Noninterest income and financial performance at U.S. commercial banks. Financial Review, 39(1), 101-127. https://doi.org/10.1111/j.0732-8516.2004.00069.x

DeYoung, R., \& Roland, K.P. (2001). Product mix and earnings volatility at commercial banks: Evidence from a degree of total leverage model. Journal of Financial Intermediation, 10(1), 54-84. https://doi.org/10.1006/jfin.2000.0305

DeYoung, R., \& Torna, G. (2013). Nontraditional banking activities and bank failures during the financial crisis. Journal of Financial Intermediation, 22(3), 397-421. https://doi.org/10.1016/j. jfi.2013.01.001

Doan, A-.T., Lin, K-.L., \& Doong, S-.C. (2018). What drives bank efficiency? The interaction of bank income diversification and ownership. International Review of Economics \& Finance, 55(May), 203-219. https://doi.org/10.1016/j.iref.2017.07.019

Doumpos, M., Gaganis, C., \& Pasiouras, F. (2016). Bank diversification and overall financial strength: International evidence. Financial Markets, Institutions \& Instruments, 25(3), 169213. https://doi.org/10.1111/fmii.12069

Elsas, R., Hackethal, A., \& Holzhäuser, M. (2010). The anatomy of bank diversification. Journal of Banking \& Finance, 34(6), 1274-1287. https://doi.org/10.1016/j.jbankfin.2009.11.024

Fahlenbrach, R., Prilmeier, R., \& Stulz, R. M. (2018). Why does fast loan growth predict poor performance for banks? Review of Financial Studies, 31(3), 1014-1063. https://doi.org/10.1093/ $\mathrm{rfs} / \mathrm{hh} \times 109$ 
Foos, D., Norden, L., \& Weber, M. (2010). Loan growth and riskiness of banks. Journal of Banking \& Finance, 34(12), 2929-2940. https://doi.org/10.1016/j.jbankfin.2010.06.007

Gallo, J., Apilado, V., \& Kolari, J. (1996). Commercial bank mutual fund activities: Implications for bank risk and profitability. Journal of Banking \& Finance, 20(10), 1775-1791. https://doi. org/10.1016/S0378-4266(96)00024-6

Goddard, J., Molyneux, P., \& Wilson, J. O. (2004). The profitability of European banks: A crosssectional and dynamic panel analysis. The Manchester School, 72(3), 363-381. https://doi. org/10.1111/j.1467-9957.2004.00397.x

Hidayat, W.Y., Kakinaka, M., \& Miyamoto, H. (2012). Bank risk and non-interest income activities in the Indonesian banking industry. Journal of Asian Economics, 23(4), 335-343. http://dx.doi. org/10.1016/j.asieco.2012.03.008

Jensen, M.C. (1986). Agency costs of free cash flow, corporate finance, and takeovers. The American Economic Review, 76(2), 323-329.

Kim, D., \& Sohn, W. (2017). The effect of bank capital on lending: Does liquidity matter? Journal of Banking \& Finance, 77(1), 95-107. https://doi.org/10.1016/j.jbankfin.2017.01.011

Köhler, M. (2014). Does non-interest income make banks more risky? Retail- versus investmentoriented banks. Review of Financial Economics, 23(4), 182-193. https://doi.org/10.1016/j. rfe.2014.08.001

Laeven, L., \& Levine, R. (2007). Is there a diversification discount in financial conglomerates? Journal of Financial Economics, 85(2), 331-367. https://doi.org/10.1016/j.jfineco.2005.06.001

Lee, C.C., Yang, S.J., \& Chang, C.H. (2014). Non-interest income, profitability, and risk in banking industry: A cross-country analysis. The North American Journal of Economics and Finance, 27(January), 48-67. https://doi.org/10.1016/j.najef.2013.11.002

Lepetit, L., Nys, E., Rous, P., \& Tarazi, A. (2008). The expansion of services in European banking: Implications for loan pricing and interest margins. Journal of Banking \& Finance, 32(11), 2325-2335. https://doi.org/10.1016/j.jbankfin.2007.09.025

Mankiw, N.G. (1986). The allocation of credit and financial collapse. The Quarterly Journal of Economics, 101(3), 455-470. https://doi.org/10.2307/1885692

Maudos, J., \& De Guevara, J.F. (2004). Factors explaining the interest margin in the banking sectors of the European Union. Journal of Banking \& Finance, 28(9), 2259-2281. https://doi. org/10.1016/j.jbankfin.2003.09.004

Meslier, C., Tacneng, R., \& Tarazi, A. (2014). Is bank income diversification beneficial? Evidence from an emerging economy. Journal of International Financial Markets, Institutions and Money, 31(July), 97-126. https://doi.org/10.1016/j.intfin.2014.03.007

Nguyen, H.T.K., \& Nguyen, D.T. (2018). Globalisation and bank performance in Vietnam. Malaysian Journal of Economic Studies, 55(1), 49-70. https://doi.org/10.22452/MJES.vol55no1.3

Nguyen, J. (2012). The relationship between net interest margin and noninterest income using a system estimation approach. Journal of Banking \& Finance, 36(9), 2429-2437. https://doi. org/10.1016/j.jbankfin.2012.04.017

Nguyen, M., Skully, M., \& Perera, S. (2012). Market power, revenue diversification and bank stability: Evidence from selected South Asian countries. Journal of International Financial Markets, Institutions and Money, 22(4), 897-912. https://doi.org/10.1016/j.intfin.2012.05.008

Petersen, M.A., \& Rajan, R.G. (1995). The effect of credit market competition on lending relationships. The Quarterly Journal of Economics, 110(2), 407-443. https://doi.org/10.2307/ 2118445

Puri, M., Rocholl, J., \& Steffen, S. (2011). On the importance of prior relationships in bank loans to retail customers (ECB Working Paper No. 1395). Retrieved from https://www.ecb.europa.eu/ pub/pdf/scpwps/ecbwp1395.pdf?c8a9d80f7c29448f0d67d0685afe4008

Roodman, D. (2009). How to do Xtabond2: An introduction to difference and system GMM in Stata. The Stata Journal, 9(1), 86-136. https://doi.org/10.1177/1536867X0900900106 
Salas, V., \& Saurina, J. (2002). Credit risk in two institutional regimes: Spanish commercial and savings banks. Journal of Financial Services Research, 22(3), 203-224. https://doi. org/10.1023/A:1019781109676

Shim, J. (2013). Bank capital buffer and portfolio risk: The influence of business cycle and revenue diversification. Journal of Banking \& Finance, 37(3), 761-772. https://doi.org/10.1016/j. jbankfin.2012.10.002

Stiroh, K.J. (2004). Diversification in banking: Is noninterest income the answer? Journal of Money, Credit, and Banking, 36(5), 853-882. https://doi.org/10.1353/mcb.2004.0076

Vo, X.V. (2018). Bank lending behavior in emerging markets. Finance Research Letters, 27(December), 129-134. https://doi.org/10.1016/j.frl.2018.02.011

Williams, B. (2016). The impact of non-interest income on bank risk in Australia. Journal of Banking \& Finance, 73(December), 16-37. https://doi.org/10.1016/j.jbankfin.2016.07.019

Windmeijer, F. (2005). A finite sample correction for the variance of linear efficient two-step GMM estimators. Journal of Econometrics, 126(1), 25-51. https://doi.org/10.1016/j. jeconom.2004.02.005

Zellner, A., \& Theil, H. (1962). Three-stage least squares: Simultaneous estimation of simultaneous equations. Econometrica, 30(1), 54-78. https://doi.org/10.2307/1911287 
